\title{
Utilization of leaf and fruit extracts of kedondong (Spondias dulcis Forst) as a supporting material for energy conversion in dye sensitized solar cells and electrochemical cells
}

\author{
Agus Malik Ibrahim,", Boima Situmeang'1, Ahmad Rifa'i', and Afif \\ Hidayatul Mustafid ${ }^{1}$ \\ 'Department of Chemistry, Sekolah Tinggi Analis Kimia Cilegon, Cilegon, Banten, Indonesia \\ *Corresponding author: AMI, sezhomalik@gmail.com
}

DOI: 10.24114/jpkim.v13i1.24140

Article history:

Received: 01 December 2020

Revised: 17 March 2021

Accepted: 19 March 2021

\begin{abstract}
This study aims to obtain a dye sensitized solar cell (DSSC) prototype and a voltaic cell prototype using the kedondong plant (Spondias dulcis Forst). Kedondong leaves as a source of chlorophyll were deliberately chosen to be in line with the use of kedondong fruit as a material for electrochemical cells, so that two research results could be obtained from the kedondong plant. This research is for the application of scientific development, increasing the added value of kedondong plant, and as support for the use of environmentally friendly energy. Research methods in general are chlorophyll extraction, citric acid isolation, chlorophyll testing, DSSC assembly, electrochemical cell assembly, and performance testing for both DSSC and electrochemical cells. The analysis results show that typical peaks appear for the functional groups in chlorophyll at certain wave numbers. Hydroxyl $(-\mathrm{OH})$ groups appear in the range of $3650-3200 \mathrm{~cm}^{-1}$, the $\mathrm{C}=\mathrm{C}$ group at $1700-1500 \mathrm{~cm}^{-1}$, the C-N group at $1350-1000 \mathrm{~cm}^{-1}$, and the C-O group at $1300-1000 \mathrm{~cm}^{-1}$. Quantitative testing used a UVVis spectrophotometer at $645 \mathrm{~nm}$ and $633 \mathrm{~nm}$, the results obtained were chlorophyll a was 4.52 $\mathrm{mg} / \mathrm{L}$, chlorophyll b was $8.43 \mathrm{mg} / \mathrm{L}$, and total chlorophyll was $12.95 \mathrm{mg} / \mathrm{L}$. The DSSC prototype performance test with a size of only $2.5 \mathrm{~cm}^{2}$, can produce a minimum voltage of $30.1 \mathrm{mV}$ and a maximum of $280 \mathrm{mV}$. The electrochemical test of kedondong citric acid extract showed that the value of the electric voltage ranged from 121 to $630 \mathrm{mV}$.
\end{abstract}

Keywords: Kedondong, Chlorophyll, DSSC, Citric acid, Electrochemical cells

\section{Introduction}

The human need for energy that is environmentally friendly and efficient has spurred the development of research based on renewable energy and natural 
energy. The energies that plenty available in tropical countries are solar, solar energy, and energy derived from electrochemical reactions. Solar energy can be converted into electrical energy using solar cells, while chemical energy can be converted into electricity through a series of electrochemical cells or voltaic cells. Solar cells are commonly found in silicon-based, but in the last two decades dye sensitized solar cells (DSSC) have been discovered which can replace silicon solar cells as an energy converter). The DSSC solar cell is photoelectrochemical sensitive to dyes by transferring an electric charge. The advantages of DSSC include cheap production, variety of materials used, environmentally friendly, and high efficiency (Cari \& Boisandi, 2013). The environmentally friendly and economical nature of the DSSC is due to the type of solar cell that can be made by utilizing natural dyes or pigments from plants that are available in nature such as chlorophyll and anthocyanins. This property also applies to electrochemical cells that use electrolytes from natural compounds contained in plants.

Dye sensitized solar cell (DSSC) is a solar cell that utilizes color pigments (dye). The standard DSSC suite mimics the photosynthetic process with four main components: dye as a sensitizer, metal oxide-based semiconductor as a photoanode, redox electrolyte (usually iodide/triiodide), and counter electrode. The counter electrode (CE) is an important part of the DSSC, because it accepts electrons from external loads and catalyzes the $\mathrm{I}^{3-}$ to $\mathrm{I}^{-}$reduction in electrolytes (Prasad et al. 2018).

The kedondong plant (Spondias dulcis Forst) is rich in various classes of secondary metabolites, including acid compounds, phenolics, sterols, triterpenes, saponins, essential oils, amino acids, and polysaccharides (Gurning et al. 2021; Simorangkir et al. 2021; Juwitaningsih et al. 2021). Members of the genus Spondias are widely used in traditional medicine for the treatment of various diseases, including abdominal pain, diarrhea, diabetes, dementia, anemia, dysentery, and various infections (Sameh et al. 2018).

The main focus of this research is the use of chlorophyll extracted from kedondong leaves, because chlorophyll is an important pigment stored in leaves for the transformation of solar radiation energy into chemical energy ( $M a$ et al. 2018; Amin et al. 2019). Increasing the efficiency of DSSC can be done by changing anode photo using titanium dioxide ( $\mathrm{TiO}_{2}$ ) (Shu et al. 2013). There are several types of chlorophyll compounds. Chlorophyll a, which is greenish yellow in solution, is the main photosynthetic pigment in green plants for the transfer of light energy to chemical acceptors. Absorbed light provides energy for photosynthesis. Green leaves absorb blue light (mostly at $430 \mathrm{~nm}$ ) and red light (mostly at $660 \mathrm{~nm}$ ). This reflects the green wavelength, and appears green to the human eye (Inanc, 2011).

The second focus is the use of citric acid isolates from kedondong fruit as a source of electrolytes for electrochemical cells. Citric acid is a weak organic acid with the chemical formula $\mathrm{C}_{6} \mathrm{H}_{8} \mathrm{O}_{7}$. Citric acid has the IUPAC name, 2-hydroxy-1,2,3propanatrikarboxylic acid (Ciriminna et al. 2017). This compound is a good and natural 
preservative, apart from being used as a sour taste enhancer in foods and soft drinks. In biochemistry, citric acid is known as an intermediate in the citric acid cycle that occurs in the mitochondria, which is important in the metabolism of living things. This substance can also be used as an environmentally friendly cleaning agent and as an antioxidant.

This study aims to obtain a dye sensitized solar cell (DSSC) prototype and a voltaic cell prototype using the kedondong plant (Spondias dulcis Forst) as a source of supporting material. The purpose of this research is for the application of scientific development, increasing the added value of high economic value from the kedondong plant, and as support for the use of environmentally friendly energy.

\section{Methods}

\subsection{Chlorophyll Extraction}

Extraction using the maceration method. The leaves of kedondong are cleaned, drained, cut into small pieces, and weighed as much as $100 \mathrm{~g}$, then mashed using a blender. The finer the kedondong leaves, the better the extraction results. The smooth kedondong leaves are then mixed with $500 \mathrm{~mL}$ acetone in a beaker and stirred using a magnetic stirrer for 30 minutes. After the chlorophyll is extracted from the leaves marked with the solution turning green and the leaf color turning white, then filtering is carried out using filter paper so that a chlorophyll solution is obtained. Chlorophyll extract is stored in a dark bottle and tightly closed, because chlorophyll is an unstable compound.

\subsection{Isolation of Citric Acid}

The skin of the kedondong fruit is peeled, the flesh is cut into pieces, then crushed using a blender. The results of the crushing are squeezed to take the liquid part. The acidity level $(\mathrm{pH})$ of the fruit liquid is measured, and neutralization is carried out using $10 \% \mathrm{NaOH}$ solution to obtain a $\mathrm{pH}$ value of 9 . The solution is then filtered to take the filtrate. The filtrate obtained was added with $28.5 \mathrm{~g}$ of $\mathrm{CaCl}_{2}$ which was dissolved in $70 \mathrm{~mL}$ of distilled water, then heated on a hot plate while stirring continuously until a precipitate of tricalcium citrate was formed. The solution is then filtered to obtain a precipitate of tricalcium citrate. The precipitate was rinsed repeatedly using hot water. The precipitate was separated into a beaker and $20.9 \mathrm{~mL}$ of concentrated sulfuric acid which had been dissolved in $200 \mathrm{~mL}$ of distilled water were added while stirring. The solution is then filtered to take the filtrate. The filtrate is heated on a hot plate while stirring using a magnetic stirrer. The heating was stopped until the remaining solution was about $70 \mathrm{~mL}$. The solution is then filtered to take the filtrate. The final solution is a solution of citric acid isolate which is ready to be used as an electrochemical cell electrolyte and is ready to be tested for its performance. If the solution is allowed to stand for several days, it forms crystals of citric acid. 


\subsection{Qualitative Test for Chlorophyll}

Typical functional groups of chlorophyll were tested using the Perkin Elmer Fourier transform infrared (FTIR) spectrophotometer, type spectrum two. The typical peaks that appear at a certain wave number indicate the vibrations of the chemical bonds of that particular group.

\subsection{Quantitative Test for Chlorophyll}

Chlorophyll content from the extract of kedondong leaves was tested using a UVVis spectrophotometer instrument. The chlorophyll extract obtained from the extraction process was then centrifuged at $1000 \mathrm{rpm}$ for 10 minutes, then the supernatant substance was taken. The centrifuged extract was then taken $1 \mathrm{~mL}$ to be diluted into a $10 \mathrm{~mL}$ measuring flask. The chlorophyll concentration was obtained from the absorbance measurement of the extract at a wavelength of $663 \mathrm{~nm}$ and 645 $\mathrm{nm}$ with a UV-Vis spectrophotometer (Aryanti et al. 2016). The chlorophyll concentration was calculated using the Arnon method.

\subsection{Preparation of Conductive Transparent Glass}

The conductive transparent glass used is a type of indium-tin-oxide (ITO) with a size of $2.5 \mathrm{~cm} \times 2.5 \mathrm{~cm}$. Making one DSSC prototype requires two transparent conductive glasses. The two transparent conductive glasses are used for counter electrodes, one for $\mathrm{TiO}_{2}$ paste, dye solution, and electrolyte. Cutting of conductive transparent glass is carried out using a glass cutter.

\subsection{Preparation of $\mathrm{TiO}_{2}$ Paste}

$\mathrm{TiO}_{2}$ powder is added slowly until a paste of the desired viscosity is obtained. Setting the concentrated nitric acid solution by adjusting $7.5 \mathrm{~mL}$ of concentrated nitric acid and adding $0.5 \mathrm{~g}$ of $\mathrm{TiO}_{2}$ powder aims to obtain the optimal paste.

\subsection{Electrolyte Preparation}

Total of $0.8 \mathrm{~g}$ of $0.5 \mathrm{M} \mathrm{KI}$ was mixed and stirred evenly into $10 \mathrm{~mL}$ of PEC 400 solution. Then $0.127 \mathrm{~g}$ of $\mathrm{I}_{2}$ was added to the solution until the three ingredients dissolved completely. The electrolyte solution is stored first in a closed vial.

\subsection{Counter Electrode Preparation}

Carbon counter electrode is made by burning the substrate to be used as a counter electrode using a candle flame. Carbon will automatically form in the area of the substrate.

\subsection{DSSC Assembly}

Assembly is carried out after all the material components have been made. First the ITO substrate is cut to a size of $2.5 \times 2.5 \mathrm{~cm}^{2}$. Scotch tape is used to limit and 
shape the area where $\mathrm{TiO}_{2}$ paste with a size of $2 \times 2 \mathrm{~cm}^{2}$ using the doctor blade method, $\mathrm{TiO}_{2}$ paste is flattened using a stirring rod. The $\mathrm{ITO}^{-\mathrm{TiO}_{2}}$ substrate was heated in a furnace at a temperature of $450{ }^{\circ} \mathrm{C}$ for 30 minutes. The deposited ITO- $\mathrm{TiO}_{2}$ substrate was then immersed for 1 day in chlorophyll solution. After blending, drop the electrolyte solution evenly. The final step, attach the active electrode substrate to the counter electrode using a binder clip with each end of the substrate given an offset of $0.5 \mathrm{~cm}$.

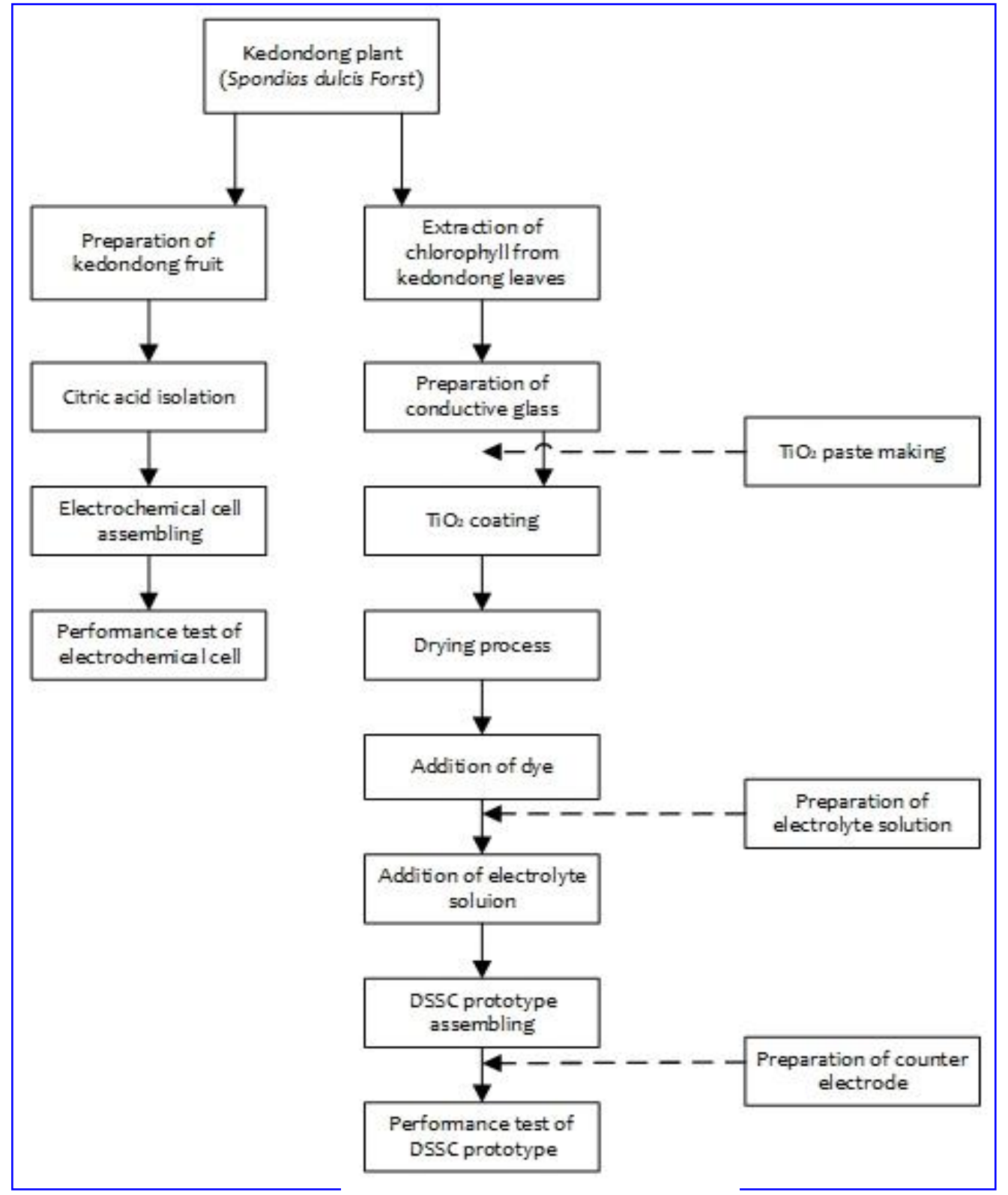

Fig 1. General flow chart of research

\subsection{DSSC Performance Test}

After the DSSC prototype has been made, then the DSSC performance test is carried out through direct lighting in the sun. Measurement by conducting an open 
circuit voltage will be obtained, the open circuit voltage $\left(V_{o c}\right)$ is obtained, by applying a load using a multimeter to form a voltage curve. The results of the DSSC were recorded, and measurements were made at intervals a few days later without being exposed to sunlight, and further measurements were taken after being given the effect of solar irradiation. The DSSC performance test was carried out within a period of 3 months to find out how much reduction the DSSC's capacity to store energy.

\subsection{Electrochemical Cell Assembly and Performance Testing}

The manufacture of an electrochemical cell begins by placing an electrolyte solution into a beaker. The beaker is incorporated copper metal and zinc metal as electrodes. Copper functions as a cathode and zinc serves as anode. Electric voltage is measured using a multimeter connected to copper and zinc metals. The flow chart or general steps of this research was presented in Fig 1.

\section{Results and Discussion}

3.1 Qualitative Test of Chlorophyll Extract from Kedondong Leaf

Qualitative testing of functional groups on extracted chlorophyll compounds was carried out using the Fourier transform infra red (FTIR) instrument. This test aims to convince that the kedondong leaves to be used for DSSC applications contain chlorophyll compounds in them.

The wave numbers around 1730 and $1700 \mathrm{~cm}^{-1}$ correspond to the keto $\mathrm{C}=\mathrm{O}$ peak in chlorophyll. A peak of about $1616 \mathrm{~cm}^{-1}$ corresponds to the $\mathrm{C}=\mathrm{C}$ group in the chlorophyll and its derivatives. The $\mathrm{C}-\mathrm{N}$ group was identified at $1466 \mathrm{~cm}^{-1}$ and the $\mathrm{C}-\mathrm{H}$ group at $1444 \mathrm{~cm}^{-1}$. The wave number around $1280 \mathrm{~cm}^{-1}$ was identified as the $\mathrm{C}-\mathrm{O}$ strain vibration for the ester group ( $\mathrm{Li}$ et al. 2018). The FTIR spectrogram of chlorophyll is presented in Fig 2 in an orange (orange) spectrogram.

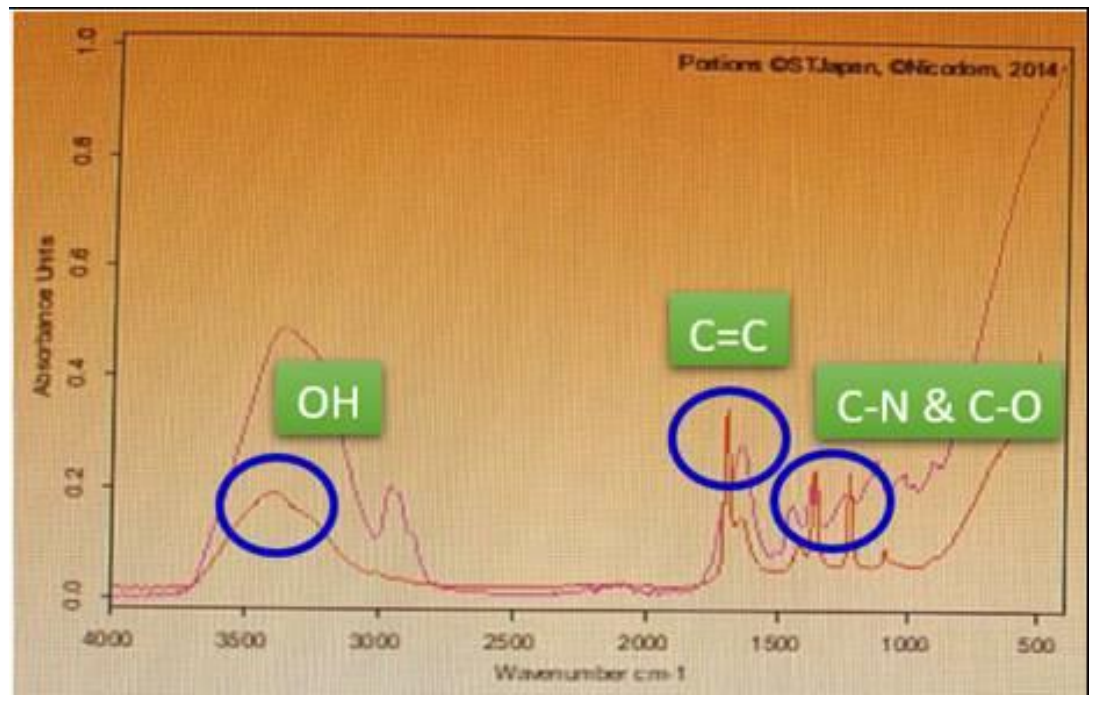

Fig 2. FTIR test results of chlorophyll extract 
The appearance of these typical peaks is because the functional group is present in the structure of the chlorophyll compound. The chemical bonds or functional groups emit vibrational energy that is read by the detector, both by absorbance and transmittance when given an energy source from infrared rays on the FTIR instrument.

\subsection{Quantitative Test of Chlorophyll Extract from Kedondong Leaf}

Quantitative testing was carried out using a UV-Vis spectrophotometer instrument at $645 \mathrm{~nm}$ and $633 \mathrm{~nm}$ wavelengths. Based on the results of the analysis of the chlorophyll extract of kedondong leaves using the UV-Vis instrument at a wavelength of $645 \mathrm{~nm}$, the absorbance results were 0.461 and at a wavelength of $663 \mathrm{~nm}$ the absorbance results were 0.454 . The results of absorbance measurements of the chlorophyll extract of kedondong leaves using a UV-Vis spectrophotometer are presented in Fig 3.

The absorbance results obtained were calculated by calculating the chlorophyll concentration using the Arnon method. Based on the results of calculating the chlorophyll concentration of kedondong leaves, it was found that the chlorophyll a content was $4.52 \mathrm{mg} / \mathrm{L}$, the chlorophyll b content was $8.43 \mathrm{mg} / \mathrm{L}$, and the total chlorophyll content was $12.95 \mathrm{mg} / \mathrm{L}$.

The results of this chlorophyll content are very important because chlorophyll compounds contain electrons which can be excited when they absorb light (Nurdin, 1997). Chlorophyll compounds play a very important role in the DSSC because it is provide electrons. Without the availability of enough electrons, there will be no voltage and no electric current. Apart from chlorophyll, natural dyes that can be used as a provider of electrons in DSSC are anthocyanins.

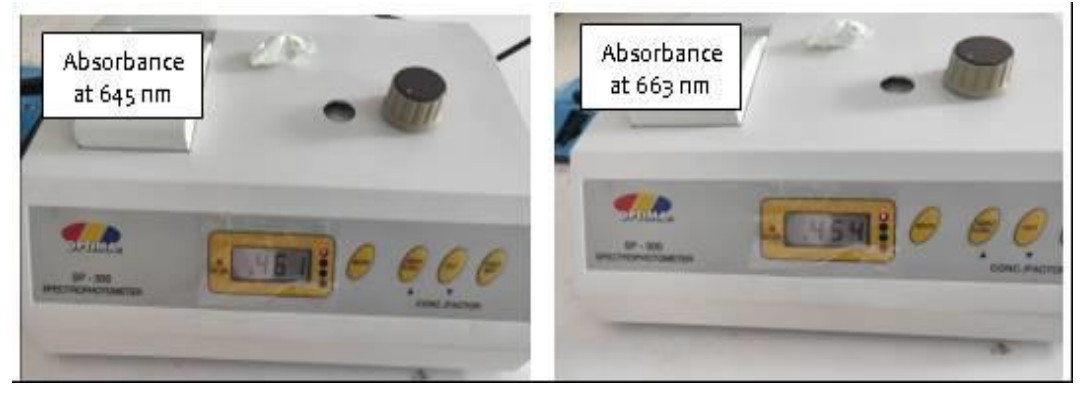

Fig 3. Measurement of the absorbance of chlorophyll extract of kedondong leaves

\subsection{DSSC Prototype Performance Test}

The DSSC prototype has been successfully assembled according to the later stages of the procedure and performed a performance test. The number of prototypes that have been made in this study is 3 units. Fig 4 shows the form of the DSSC prototype that was successfully made. 
In this study, the DSSC performance test was carried out after obtaining the DSSC prototype and the initial measurements were made on the DSSC prototype using a multimeter without prior direct sunlight treatment. Furthermore, given direct sun irradiation for 1 hour and direct sunlight for 4 hours. The test was carried out 7 days later without being given solar radiation treatment. This situation is deliberately left alone so that the value of the output voltage $\left(V_{\text {out }}\right)$ continues to fall until it reaches the lowest value. After reaching the lowest value, re-measurement was carried out with the same prototype by being given treatment in two conditions, namely before direct solar irradiation and after direct solar irradiation for 1 hour and direct sunlight for 4 hours. In general, based on the research data obtained, it is proven that chlorophyll is an important pigment stored in leaves for the transformation of solar radiation energy into chemical energy ( $M a$ et al. 2018). Fig 5 shows the measurement results of the DSSC prototype performance test for 3 months.
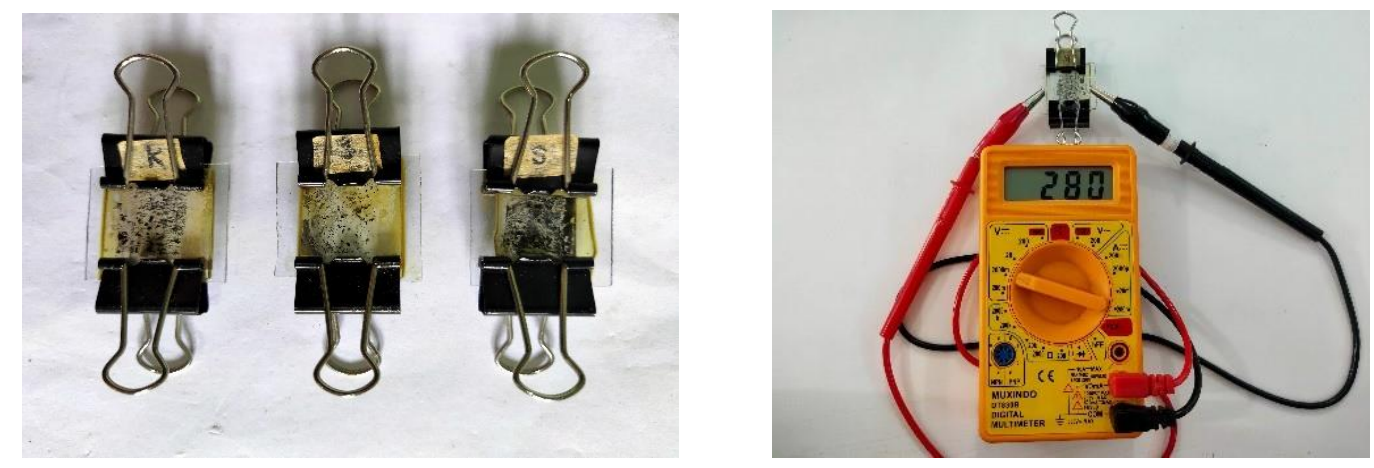

Fig 4. DSSC prototype and the testing

The results of the performance test showed that the DSSC prototype of kedondong leaf, with only $2.5 \mathrm{~cm}^{2}$ in size, was able to produce a maximum voltage of $280 \mathrm{mV}$ on March 5, 2020. This is due to the ability of DSSC to store energy so that it generates a lot of electrons which causes the voltage value to increase the ability of DSSC chlorophyll from kedondong leaves as an energy converter. On May 7, 2020, it was found that the voltage reached a minimum value of $21.1 \mathrm{mV}$. This is due to decreased energy storage capacity in the DSSC of kedondong leaves.

The initial measurement of the DSSC prototype on March 5, 2020, obtained a voltage of $280 \mathrm{mV}$. Then given direct sunlight treatment for 1 hour, the result was the voltage decreased by $44 \%$ to $156.5 \mathrm{mV}$ this was due to cloudy weather conditions. Then given direct solar irradiation for 4 hours, the result was the voltage increased by $15 \%$ to $180.5 \mathrm{mV}$. These results prove the important role of the sun as a source of energy for living things, as well as prove the ability of the DSSC chlorophyll leaves of kedondong as an energy converter. Furthermore, the test was carried out 7 days later on March 12, 2020 without previously being given solar radiation treatment, the voltage value decreased by $1 \%$ to $277 \mathrm{mV}$. This situation is deliberately left alone so that the voltage value continues to fall until it reaches the lowest value. After 
reaching the lowest value, repeated measurements were carried out with the same prototype (kedondong leaf) by being given direct sunlight for 1 hour, the result was that the voltage dropped by $57 \%$ to $118.8 \mathrm{mV}$ this was due to cloudy weather conditions. Then given direct sunlight irradiation for 4 hours, the result was the voltage increased by $54 \%$ to $182.7 \mathrm{mV}$.

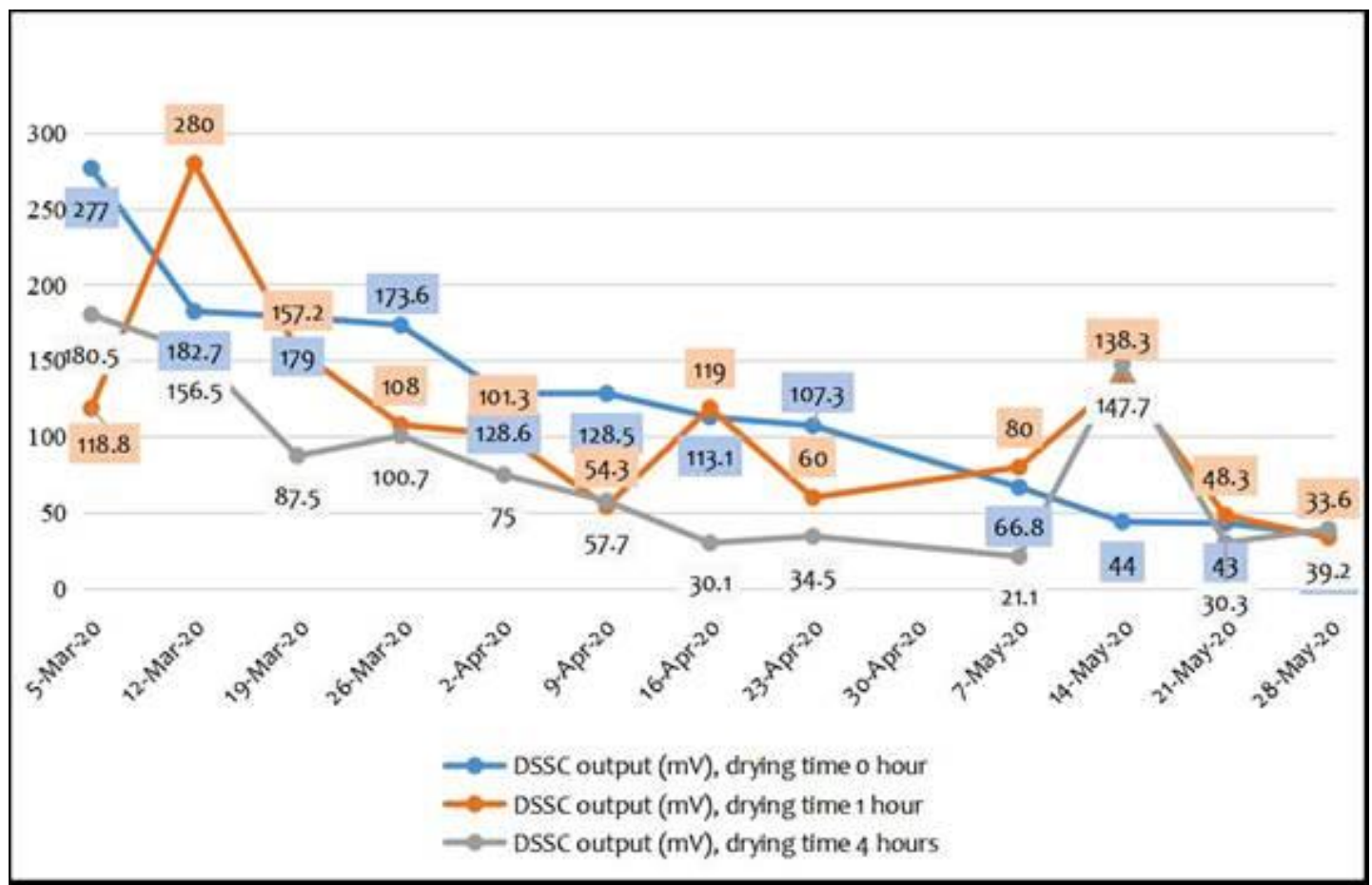

Fig 5. The measurement results of DSSC prototype performance test for 3 months

The chart in Figure 5 shows that the value of the DSSC output voltage for the chlorophyll extract of kedondong leaves will slightly decrease during use. The measurement results in March 2020 showed that the DSSC output voltage value decreased by $38 \%$ to $173.6 \mathrm{mV}$ from the initial measurement of $280 \mathrm{mV}$. Meanwhile, in April 2020 and May 2020, the DSSC output voltage value decreased by $17 \%$ and $47 \%$. This means that the energy storage in the dye decreases over time.

\subsection{Qualitative Test and Electrochemical Test of Citric Acid from Extraction}

Citric acid extract testing was carried out using the Fourier transform infra red (FTIR) instrument. The test was carried out at a wave number of $550-800 \mathrm{~cm}^{-1}$ because very few functional groups were detected through the test. Based on the similarity, the extract obtained has a spectrum pattern that resembles the spectrum of citric acid with a concentration of $20 \%$ and a $\mathrm{C}-\mathrm{H}$ group is detected at a wave number of $650-700 \mathrm{~cm}^{-1}$ (Field et al. 2008). The test result spectrogram was presented in Fig 6 and electrochemical test of citric acid extract was presented in Fig 7 . 

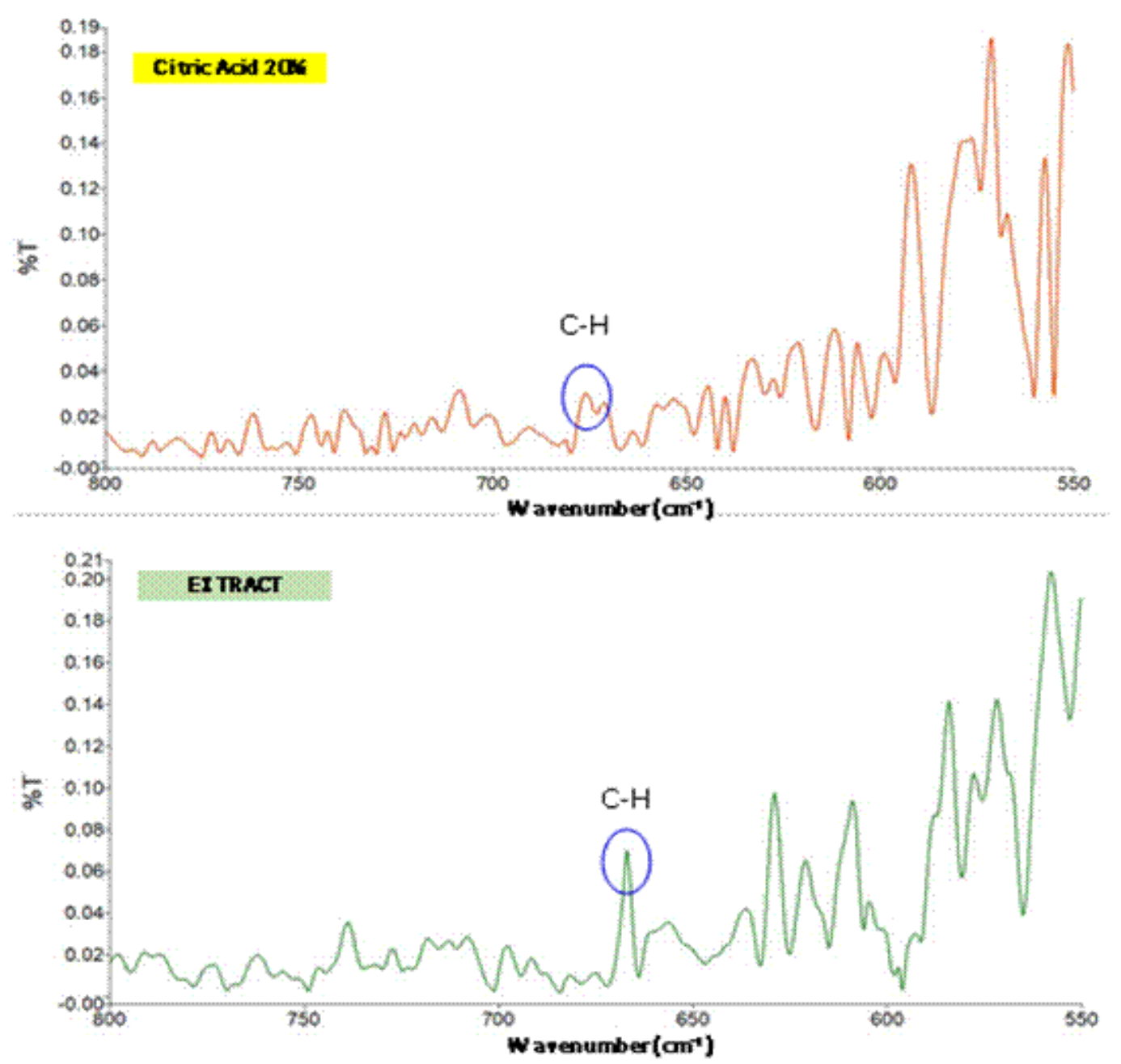

Fig 6. Test results of citric acid extract using FTIR

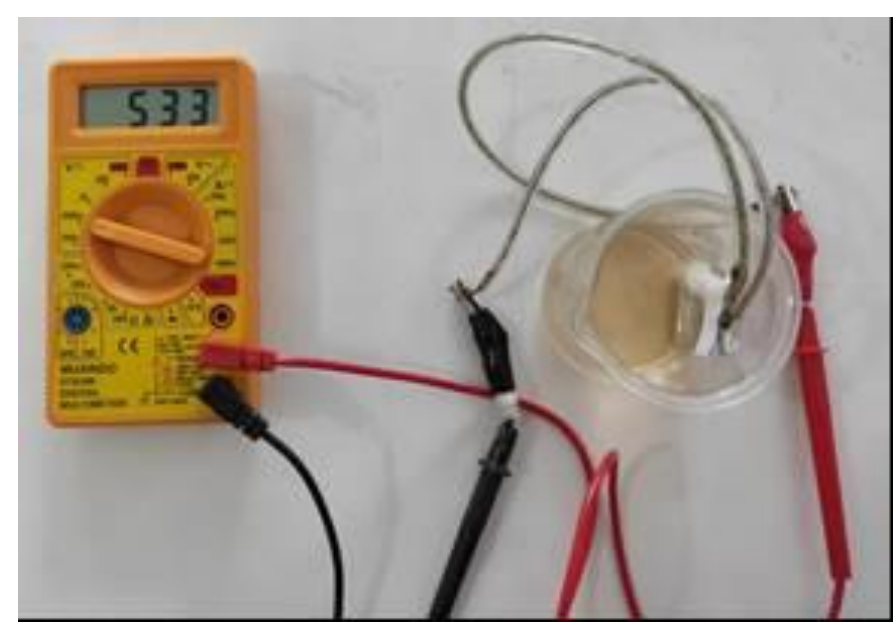

Fig 7. Electrochemical test of citric acid extract

The electrochemical test of kedondong citric acid extract showed that the value of the electric voltage ranged from 121 to $630 \mathrm{mV}$. This value is still relatively low and not sufficient to be used as a main source of electricity, for example to replace a 
battery. Citric acid does not generate electricity by itself. Acids are a source of electrolytes because they easily ionise into cations and anions in the solvent, which causes the solution to become an electrolyte solution. The electrolyte then generates electricity through the electron transfer mechanism at the electrodes (anode and cathode) (Sultana et al. 2018; Shittu et al. 2018).

\section{Conclusion}

This research proves that leaf and fruit extracts of kedondong (Spondias dulcis Forst) can used as a supporting material for energy conversion in dye sensitized solar cells (DSSC) and electrochemical cells. The results of the DSSC prototype performance test with a size of only $2.5 \mathrm{~cm}^{2}$, able to produce a minimum voltage of $30.1 \mathrm{mV}$ and a maximum of $280 \mathrm{mV}$. The electrochemical test of kedondong citric acid extract shows that the value of the electric voltage ranged from 121 to $630 \mathrm{mV}$. Analysis of chlorophyll extract with FTIR show that hydroxyl (-OH) groups appear in the range of wave numbers $3650-3200 \mathrm{~cm}^{-1}$, the $\mathrm{C}=\mathrm{C}$ group at $1700-1500 \mathrm{~cm}^{-1}$, the $\mathrm{C}$ $\mathrm{N}$ group at $1350-1000 \mathrm{~cm}^{-1}$, and the $\mathrm{C}-\mathrm{O}$ group at $1300-1000 \mathrm{~cm}^{-1}$. Quantitative testing used a UV-Vis spectrophotometer at $645 \mathrm{~nm}$ and $633 \mathrm{~nm}$ wavelengths shows that the content of chlorophyll a in extract was $4.52 \mathrm{mg} / \mathrm{L}$, chlorophyll b was $8.43 \mathrm{mg} / \mathrm{L}$, and total chlorophyll was $12.95 \mathrm{mg} / \mathrm{L}$.

\section{Acknowledgment}

The author would like to appreciate and kindly acknowledge the Ministry of Research, Technology, and High Education (RISTEKDIKTI) for the research funds provided. The author also appreciates and kindly acknowledges LLDIKTI Region IV for support in the Beginner Lecturer Research (PDP) program in 2020.

\section{References}

Amin, F., Mahardika, M., \& Morisca, N. (2019). Synthesis and characterization of gold nanoparticles using fruit extract of Crescentia cujete L. Jurnal Pendidikan Kimia, 11(3), 9599. DOl: 10.24114/jpkim.v11i3.15737

Aryanti, N. (2016). Ekstraksi dan karakterisasi klorofil dari daun suji (Pleomele angustifolia) sebagai pewarna pangan alaml. Jurnal Aplikasi Teknologi Pangan, 5(4), 129-135. DOI: 10.17728/jatp.196

Cari, N., Boisandi, A., \& Supriyanto Agus, S. R. (2013). Studi pengaruh konsentarasi Poly (3Hexylthiophene)(P3HT) terhadap peningkatan efisisensi dye sentisitized solar cells. In Seminar Nasional 2nd Lontar Physics Forum.

Ciriminna, R., Meneguzzo, F., Delisi, R., \& Pagliaro, M. (2017). Citric acid: emerging applications of key biotechnology industrial product. Chemistry Central Journal, 11(1). DOI: 10.1186/s13065-017-0251-y

Field, L.D., Sternhell, S., \& Kalman, J.R. (2008). Organics Structures from Spectra $4^{\text {th }}$ Edition. John Wiley \& Sons Ltd: West Sussex. 
Gurning, K., Simanjuntak, H. A., Purba, H., Situmorang, R. F. R., Barus, L., \& Silaban, S. (2021). Determination of total tannins and antibacterial activities ethanol extraction seri (Muntingia calabura L.) leaves. Journal of Physics: Conference Series, 1811, 012121. DOI: 10.1088/1742-6596/1811/1/012121

Inanç, A. L. (2011). Chlorophyll: Structural properties, health benefits and its occurrence in virgin olive oils. Akademik Gıda, 9(2), 26-32.

Juwitaningsih, T., Sari, S. A., Jahro, I. S., Silaban, S., \& Simorangkir, M. (2021). Study of phytochemical, antibacterial activity and toxicity on acetone extract seed Leersia hexandra Sw. Journal of Physics: Conference Series, 1811, 012130. DOI: 10.1088/1742$6596 / 1811 / 1 / 012130$

Li, X., Zhou, R., Xu, K., Xu, J., Jin, J., Fang, H., \& He, Y. (2018). Rapid Determination of Chlorophyll and Pheophytin in Green Tea Using Fourier Transform Infrared Spectroscopy. Molecules, 23(5), 1010. DOI: 10.3390/molecules23051010

Ma, X., Feng, J., Guan, H., \& Liu, G. (2018). Prediction of chlorophyll content in different light areas of apple tree canopies based on the color characteristics of 3D reconstruction. Remote Sensing 2018, 10(429), DOI: 10.3390/rs10030429.

Minh, N.P., \& Oanh, T.T.K. (2018). Fermentation of ambarella (Spondias dulcis) wine. International Journal of Applied Engineering Research, 13(2), 1324-1327.

Nurdin. (1997). Buku ajar fisiologi tumbuhan. Departemen Pendidikan dan Kebudayaan Universitas Andalas Padang: Padang.

Prasad, S., Durairaj, D., Al Salhi, M.S., Theerthagiri, J., Arunachalam, P., \& Durai, G. (2018). Fabrication of cost effective dye sensitized solar cells using sheet like $\operatorname{CoS}_{2}$ films and phthaloylchitosan based gel polymer electrolyte. Energies, 11(281), DOI: 10.3390/en11020281.

Sameh, S., Al-Sayed, E., Labib, R. M., \& Singab, A. N. (2018). Genus spondias: A phytochemical and pharmacological review. Evidence-Based Complementary and Alternative Medicine, 2018, 1-13. DOI: 10.1155/2018/5382904

Shittu, S.A., Ajagbe, S.A., \& Oloruntola, R.F. (2018). Conversion of fruit to battery. International Journal of Scientific \& Engineering Research, 9(1), 1747-1755.

Simorangkir, M., Nainggolan, B., Juwitaningsih, T., \& Silaban, S. (2021). The toxicity of nhexane, ethyl acetate and ethanol extracts of sarang banua (Clerodendrum fragrans Vent Willd) leaves by brine shrimp lethality test (BSLT) method. Journal of Physics: Conference Series, 1811, 012053. DOI: 10.1088/1742-6596/1811/1/012053

Sultana, J., Dola, K.E.J., Mahmud, S.A., \& Mazumder, A.R. (2018). Construction and evaluation of electrical properties of a lemon battery. Journal of Chemical, Biological and Physical Sciences, 8(2), 92-101. DOI: 10.24214/jcbps.C.8.2.09201.

Shu, W., Liu, Y., Peng, Z., Chen, K., Zhang, C., \& Chen, W. (2013). Synthesis and photovoltaic performance of reduced graphene oxide- $\mathrm{TiO}_{2}$ nanoparticles composites by solvothermal method. Journal of Alloys and Compounds, 563, 229-233. DOI: 10.1016/j.jallcom.2013.02.086 